\title{
IDENTITETSFORMATION I SOCIALA KONFIGURATIONER
}

\author{
PATRIK AsPERS
}

\begin{abstract}
The purpose of this article is to present a theoretical framework for analyzing the formation of identities. Individual and collective actors' identities are formed over time as a result of positioning and evaluation in what is called social configurations. Social configurations are characterized by order and values that guide, and are used for evaluation of, actors' behavior. Order in social configurations emerges according to two inverted logics: Status and Standard. Order according to Status in a configuration is a function of the firmness of actors' order of identities, which correspond with a value. Standard means that actors' order of identities is a function of how well they perform against the standard (value) that is used for evaluation. In Status the identities are more entrenched than the value, and in Standard the principle of evaluation (the value) is more entrenched than the identities of the actors. The suggested approach can handle institutionalized as well as pre-institutional aspects of social life. A more general point is that configurations are used to study how social order emerges and how it is reconstructed. The empirical examples come from the global garment industry, which has been studied with ethnographic methods.
\end{abstract}

Keywords: actor; Erving Goffman; garment industry; Harrison White; identity; market; social configuration.

Identitet är ett modeord. Mycket har skrivits om begreppet från teoretiska utgångspunkter och många empiriska studier har diskuterat identitet. Jag menar att identitet är ett begrepp som bör placeras centralt inom sociologisk teori, vilket också sker inom den samtida sociologin. Det kommer sig inte minst av hur samhället ser ut, med olika kollektiva identifikationsgrunder och där individualiseringen är tydlig (t.ex. Frank/ Meyer 2002). Det finns en omfattande diskussion om identitet, men den uppvisar enligt mig flera problem: med identitet tycks man kunna mena nästan vad som helst (jfr. Brubaker/Cooper 2000) och som en följd är den svag vad beträffar förslag på konkreta implikationer.

I den här artikeln presenteras ett teoretiskt ramverk för att analysera identitetsformation. Den teoretiska utgångspunkten är Harrison Whites teori om sociala molekyler, vilken utvecklas och kombineras med Goffmans teori om identitet och identitetskontroll (management). White (1992) utvecklar en teori som utgår från "sociala molekyler"; en sådan molekyl är den minsta enheten som kan användas för sociologisk analys, och den utgör en grund för ordning. ${ }^{1}$ Genom denna ansats är det möjligt att förstå hur ordning förekommer, och hur det motverkar osäkerhet som aktörer är utlämnade till om de inte känner till sin identitet; en osäkerhet som även kan inrymma en

* Article in Swedish. Title in English: Identity Formation in Social Configurations. 
existentiell dimension. Whites ansats innebär att en aktörs enskilda identitet endast kan förstås i relation till en kollektiv identitet som hålls samman i en konfiguration. En kombination av Whites och Goffmans arbeten formas till en teoretisk ram för förståelse av identitetsformation, ordning och genererande av värden som är annorlunda och mer konkreta än deras arbeten tagna var för sig. Konfigurationer är också ett sätt att kunna hantera institutionaliserade eller koagulerade sociala sammanhang, samtidigt som man kan hantera dem innan de institutionaliserats.

Artikeln diskuterar i första hand hur aktörers enskilda identiteter formeras genom att de erhåller positioner i ett begränsat antal sociala konfigurationer som centrerar kring olika värden. Erhållande av positioner sker i social interaktion. Artikelns huvudpoäng är att med hjälp av begreppet identitet utveckla en ram för att förklara hur olika identiteter formas i sociala konfigurationer, vilka ordnas antingen efter aktörers status eller efter en standard. Dessa konfigurationer kan sedan uppdelas i möten och gränssnitt, beroende på om aktörer i konfigurationen över tid har samma roll eller om de växlar roller. Den teoretiska ramen tillämpas för att visa hur både individer och organisationer erhåller enskilda identiteter genom interaktion i olika sociala konfigurationer över tid.

Artikelns bidrag till den existerande litteraturen är det teoretiska ramverk som presenteras för att analysera identitetsformation. Det underliggande argumentet är att identitet inte kan analyseras isolerat, utan forskaren måste analysera identitet i relation till social struktur, värde och roller. Konfiguration är ett teoretiskt redskap för att genomföra dessa analyser. Identitetsformationer sker empiriskt i en rad olika konfigurationer, och i denna artikel studeras detta i relation till den globala klädindustrin. I nästa avsnitt diskuteras det empiriska materialet. I följande avsnitt tas teori om identitet och tidigare forskning på området upp, därefter presenteras artikelns bidrag, tanken om sociala konfigurationer.

\section{Fält och empiri}

Denna artikel baseras på empiriskt material från den globala klädindustrin. Denna industri är ett typiskt exempel på en global industri. Det är också en av de största industrierna, både vad gäller antalet anställda, men också vad gäller omsättning. Det finns dels tekniskt enkel produktion av kläder, som i stort sett är oförändrad de senaste 40 åren, dels finns det design som kräver specifik kunskap om konsumenterna. Design och marknadsföring är koncentrerad till huvudkontoren, som ligger nära konsumenterna, medan produktionen huvudsakligen sker i utvecklingsländer. Om man utgår från klädkedjor (t.ex. the Gap, Zara och H\&M), så är de uppköpare av tjänster för att tillverka kläder i förhållande till företag i olika länder, och de är försäljare av kläder i förhållande till konsumenter av kläderna.

Jag har studerat flera steg i den produktionskedja, vilken förbinder tillverkning av textilier (och dess insatsprodukter, t.ex. bomull med mera) med klädproduktionen och den konsumentmarknad som, så att säga, är slutsteget i denna produktionskedja. Det egna empiriska arbetet är koncentrerat till steget mellan klädkedjor och de företag $\mathrm{i}$ främst utvecklingsländer som tillverkar dessa kläder.Jag har talat med olika aktörer, inte minst inköpare hos olika klädkedjor i England och Sverige samt bland annat tillverkare i Turkiet och Indien. Förutom intervjuer (27 st.) har jag utfört observation under flera 
månaders fältarbete i dessa länder, t.ex. på modemässor och fabriker och i butiker, samt använt mig av den relativt omfattande textproduktionen som sker i fältet och självfallet även den akademiska litteraturen om detta fält. Därtill har jag använt den generella litteraturen om konsumtion, mode och konsumtionsmarknaden för kläder. Det empiriska materialet har i viss utsträckning bidragit till det teoretiska ramverk som används i artikeln, men det är i huvudsak en teoristyrd artikel. Det empiriska materialet är kodat och analyserat utifrån övergripande frågor om marknader. ${ }^{2}$

\section{Tidigare forskning om identitet}

Tanken om identitet går att spåra till Cooley och Mead. Mer samtida forskning som diskuterat identitet har huvudsakligen tagit upp kollektiv identitetsformation i förhållande till klass, kön och etnicitet, hur distinktioner upprätthålls med identiteter, identitet i relation till kropp, samt frånvaro av kropp genom användande av tekniska hjälpmedel (se Cerulo 1997; Brubaker/Cooper 2000 för översikter av forskning kring identitet). ${ }^{3}$

Om människor endast hade ett mycket kort minne och om det inte fanns nätverk som har permanens skulle individers "identiteter"- om begreppet skulle ha någon som helst mening - vara knutna till sociala situationer, och "identiteten" skulle upphöra i stort sett samtidigt som situationen upplöses. Genom minnen och olika aktiviteter upprätthålls identiteter. Detta är en förutsättning för alla diskussioner om identitet.

Det allmänna identitetsbegreppet i denna artikel följer Husserls definition, och innebär att likhet föreligger mellan två "saker". ${ }^{4}$ En första distinktion kan göras mellan kollektiv och enskild (individuell) identitet, två nivåer som är intimt relaterade och som i många fall påverkar varandra. Etnicitet, nation, klass och kön är exempel på vad som kan benämnas kollektiva identiteter, liksom exempelvis klädföretag. ${ }^{5}$ En viktig poäng i den analys som jag företar är att den kan tillämpas både på människor och organisationer.

Ett klädföretag har en identitet som just klädföretag, som självfallet delas med andra klädföretag, som de konkurrerar med. Denna identitet skiljer klädföretag från exempelvis bilföretag, men även från stubbar, bandyspelare, och snabbköpskassörskor. Det är grunden för den relationella dimensionen av den kollektiva identiteten, som innebär att en identitet endast kan föreligga i relation till andra identiteter. Kollektiv identitet kan även, enligt Husserl, benämnas som "species". Ett klädföretag har alltså samma slags uppfattade relationer (jfr. Burt 1992), egenskaper med mera som andra klädföretag, och det är dessa som konstituerar den kollektiva identiteten klädföretag; utan dessa skulle begreppet klädföretag vara meningslöst.

Varje företag har även en enskild, eller individuell, identitet som skiljer ut företaget från andra företag. Denna förutsätter jämförelse mellan olika enskilda identiteter, och med detta kommer en princip för sortering av de enskilda identiteterna, dvs. en ordningsprincip som kan användas för att skapa olikhet inom den kollektiva identiteten. För företag binds namnet, produktmixen, logotypen, kundkretsen, reklamen, företagets historia med mera samman till en identitet. Denna mix uppfattas som unik inom den kollektiva identiteten för klädföretag och är vad som konstituerar den enskilda identiteten.

Både den enskilda och den kollektiva nivån är viktig, men med dessa kan man förklara identitetsformation. Vad som delvis saknas inom den sociologiska identitets- 
litteraturen är en mer generell ram för identitetsformation, dvs. hur processerna i vilka de förvärvas ser ut, samt hur dessa processer kristalliseras och bidrar till att social struktur skapas. Jag menar att detta problem endast kan studeras om man tar hänsyn till andra aspekter som medkonstruerar identitet, i första hand värde, roller och social ordning. Det är artikelns centrala uppgift att presentera en ram som möjliggör analys av identiteter, men som just inkluderar dessa olika aspekter. Finns inte redan en sådan teoretisk ram?

Nej, men det finns åtminstone ett seriöst försök i denna riktning: Harrison Whites diskussion om identitet och kontroll, och särskilt hans idé om sociala molekyler (1992). Whites ansats kan användas för studier av både människor och organisationer, t.ex. företag (White 2002) De sociala molekylerna är de minsta enheterna som enligt White är självreproducerande och den samhällsvetenskapliga analysen bör utgå från denna nivå vid studier. White diskuterar tre typer av sociala molekyler: "Arena", "Interface" och "Council", men som påpekats är dessa närmast att se som förslag. ${ }^{6}$ White har egentligen endast skrivit om Interface, och det är därför oklart hur de andra molekylerna skall förstås.

Jag använder här ett antal grundtankar hos White, inte minst följer jag honom genom att identifiera de minsta meningsfulla sociologiska enheterna som kan skapa "ordning", samt att dessa enheter, molekyler eller i mitt fall konfigurationer, innebär värdering (jfr. White 1992: 138). Precis som White menar jag vidare att det inte går att använda en simpel kausalitetstanke där t.ex. värde är orsakat av social struktur (eller omvänt).

Min ansats skiljer sig från Whites först och främst genom att vara tydlig och förankra de teoretiska resonemangen i konkret empiri. White (se särskilt 1992: 32-3) introducerar i kapitel 2 ett 30-tal begrepp och efter att ha läst igenom recensionerna av hans teoretiska verk, Identity and Control (1992), och samtalat med White själv ${ }^{7}$ har det för mig blivit uppenbart att hans upplägg inte kan kommuniceras till läsare. Det är väldigt svårt att se hur begreppen kan fogas samman till en meningsfull enhet. En huvudkritik som kan riktas mot White är att han presenterar ett antal olika "hypoteser” om hur värde, identitet och social struktur faktiskt är avhängiga av varandra, utan att närmare beskriva hur detta sker eller genom att underbygga det med empiri som belyser det teoretiska resonemenget.

Jag använder betydligt färre begrepp än White, och beskriver även utifrån empiri hur de olika komponenterna, värde, social struktur, kultur och identitet hänger samman, vilket inte White förmår göra. Jag arbetar endast med två ordningsprinciper för konfigurationer och menar att den tredelning som White indikerar (men som han inte utvecklar) saknar empiriskt stöd. White (1992: 197) menar att nätverk är centrala, men jag hävdar att många sociala processer kan förstås utan att behöva referera till nätverk. Vidare skiljer vi oss åt genom att White (2002) grundar sitt mest avancerade modellbygge, av interfaces, i en matematisk modell, medan jag grundar min ansats i en empirisk fenomenologi, och därmed knyter an till medvetande, tolkning och förståelse (även om vi båda argumenterar för social konstruktivism). ${ }^{8}$

\section{Sociala konfigurationer}

I diskussionen nedan introduceras vad jag kallar sociala konfigurationer. ${ }^{9}$ En konfiguration definieras som en social struktur baserad på ett värde som används för att 
evaluera och skapa ordning bland enskilda identiteter som delar en kollektiv identitet. Aktörerna i en konfiguration har något gemensamt vilket gör att de hör samman och orienterar sig mot varandra. Genom evaluering inom en konfiguration kan enskilda identiteter särskiljas och ordnas. Av analytiska skäl behandlas de var för sig.

Utgångspunkten i analysen är aktörers enskilda identitet, som alltså måste förstås i ljuset av den kollektiva identiteten. Här hävdas att det finns två grundläggande konfigurationer, möten och gränssnitt. Möten kännetecknas av att alla som ingår i konfigurationen har samma roller, medan gränssnitt kännetecknas av att två roller möter varandra över ett gränssnitt. Ett gränssnitt kan vidare uppdelas mellan de fall där aktörerna har permanenta rollåtagande för en sida, och de fall där de skiftar roller, och därigenom växlar sida. Gränssnitt och möten kan ordnas enligt två principer, Standard och Status. Genom konfigurationsprocessen skapas social ordning och värden etableras. I Figur 1 nedan presenteras konfigurationstypologin.

\begin{tabular}{|c|c|c|c|}
\hline \multirow[b]{2}{*}{ Ordningsprincip } & \multicolumn{3}{|c|}{ Konfigurationstypologi } \\
\hline & $\begin{array}{l}\text { Möte } \\
\text { Alla aktörer har } \\
\text { lika roller }\end{array}$ & $\begin{array}{l}\text { Gränssnitt } \\
\text { Aktörer har en roll } \\
\text { på en sida av } \\
\text { gränssnittet }\end{array}$ & $\begin{array}{l}\text { Aktörer har roller } \\
\text { på två sidor av } \\
\text { gränssnittet }\end{array}$ \\
\hline Standard & $V D$-position & Produktion av kläder & $\begin{array}{l}\text { Agenter för } \\
\text { modekläder }\end{array}$ \\
\hline Status & $\begin{array}{l}\text { Deltagare i } \\
\text { modeshow }\end{array}$ & Modeklädeskedjor & $\begin{array}{l}\text { Samtal på fest } \\
\text { för modefolk }\end{array}$ \\
\hline
\end{tabular}

Figur 1. Konfigurationstypologi för formation av enskilda identiteter givet gemensam kollektiv identitet med sex konkreta exempel.

Jag inleder med att diskutera konfigurationer abstrakt, därefter går jag över till att presentera ett antal empiriska fall utifrån den globala klädproduktionsindustrin. Den första frågan man bör ställa sig är hur identitet analyseras med hjälp av konfigurationer. Givet insikt om aktörers roller ${ }^{10}$ är analysprincipen att fråga om ordningsprincipen: Föreligger en ordning som är beroende av aktörernas positioner (Status) eller är den oberoende av aktörerna och deras positioner (Standard)? Status innebär att aktörers relativa positioner och deras interaktion är helt avgörande för värdet som konfigurationen centrerar sig kring, med andra ord vad som är "bra" och "dåligt". Standard innebär att aktörer får identiteter utifrån hur väl ("bra eller dåligt") de uppfyller standarden (jfr. Goffman 1968: 70, som talar om "bra" eller "dåliga" mödrar). De är således omvända: Vid Status är den sociala ordningen i konfigurationen en funktion av att aktörernas identiteter är hållfasta, och vid Standard är individernas identiteter en funktion av hur väl de uppfyller standarden. Vid Status skapas ett värde, en slags ordningsprincip som ett resultat av interaktion mellan aktörer; värdet konstrueras av aktörerna, medan vid Standard är ordningen oberoende av aktörerna och värdet är redan konstruerat. ${ }^{11}$ Hållfastheten för aktörers inbördes ordning samt för värdet i kon- 
figurationen är således de komponenter som skapar ordning i en konfiguration. Vid Status är hållfastheten högre för aktörernas inbördes ordning än det värde som konfigurationen centrerar sig kring. Vid Standard är det omvänt. Båda fallen möjliggör jämförelse mellan aktörer utifrån den ordningsprincip (värde) som reflekterar vad som värderas i konfigurationen. Detta är en förutsättning för att enskilda identiteter skall kunna skapas och formeras.

För att bättre förstå hur man kan använda konfigurationer för att analysera sociala fenomen följer konkreta exempel på var och en av dessa sex olika konfigurationer. Exemplen kommer från den globala klädindustrin och är ett resultat av egen forskning. Man får dock i läsningen bära med sig insikten att verkligheten sällan motsvarar teoriers idealtyper. De gör det bara med avseende på vissa aspekter. Jag inleder diskussionen med möten för att därefter ta upp gränssnitt (jämför Whites 1992-begrepp "arena" och "interface").

\section{Möten}

Standard och Möte (lika roller). När ett antal personer med lika roll och delad kollektiv identitet, t.ex. verkställande direktörer (VD:s) i klädimportföretag kommer samman föreligger en tydlig standard vilken möjliggör jämförelse mellan dem, nämligen storleken på företaget (mätt som omsättning). Givet likheten, dvs. den kollektiva identiteten som delas av företagen som har samma roll (t.ex. säljare) inom en marknad, finns en individuell skillnad $\mathrm{i}$ storlek som är en grund för företagens och VD:s enskilda identiteter. Storlek är i detta fall det värde som standardiserats och som används som jämförelse mellan företag inom näringslivet. Denna ordningsprincip är oberoende av enskilda aktörers egna preferenser och intressen. Den används av människor utanför branschen, inom näringslivet i stort, bland journalister och även av människor utan direkt koppling till industrin. Aktörerna, inklusive de olika VD:s som jämförelsen avgränsas till i detta fall, föds in i en värld som redan är standardiserad. Man kan med andra ord säga att denna standard, dvs. omsättningen är en relativt hållfast social konstruktion. ${ }^{12}$ Genom att VD:s och andra använder sig av denna standard så ökas dess hållfasthet. Man kan jämföra det med att hela konfigurationen institutionaliseras.

Denna jämförelse mellan VD:s förutsätter emellertid inte att aktörerna (VD:s) kommer samman fysiskt. Det är fullt möjligt att avgöra storleken på bolaget genom att titta på börsen. Det är även möjligt att jämföra storlek över tid (vilket också görs i varje årsredovisning). I detta fall existerar alltså standarden oberoende av de VD:s som ingår i konfigurationen. Den är vidare förutsägbar, dvs. aktörer kan orientera sig mot den.

Vad har nu detta att göra med identitet? Dessa VD:s har roller som är lika (VD), och att de delar en kollektiv identitet (klädföretag), samt delar vissa övertygelser gör att man kan tala om dem som en "species". Utvärderingen av aktiviteterna, vilket sker efter det underliggande värdet (standarden) i konfigurationen, kommer detta att påverka den enskilda identiteten för dem som är VD i klädbranschen. De kommer att ordnas efter konfigurationens standard; med andra ord innebär det att några är VD för små och andra för stora bolag. Jag utgår från att de som ingår i konfigurationen anser det vara bättre att vara VD för ett större än ett mindre bolag, allt annat lika. I vilket fall erhåller de en identitet som är en funktion av standarden, dvs. hur de positi- 
onerar sig på värdeskalan mellan små och stora klädföretag. Standarden är också i sig opåverkad av att den bidrar till aktörers identitet. Det är ingen större skillnad att genomföra denna analys på kollektiv nivå, dvs. för företag (jfr. White 2002; Aspers 1997).

I praktiken sker jämförelse mellan aktörer, inte ens inom en och samma domän singulärt. Med andra ord sker det inte via analys av en konfiguration i taget, utan identiteter för VD:s är avhängigt en mängd olika konfigurationer. Analytiskt och pedagogiskt finns det dock skäl att studera dem var för sig, men som jag kommer att diskutera nedan, måste en studie av reellt existerande identiteter beakta även andra konfigurationer.

Status och Möte (lika roller). I många fall möts aktörer som har lika roller eller inga (formella) roller. Detta är exempel på en konfiguration som är löst strukturerad och inte institutionaliserad. Den kännetecknas av låg hållfasthet, och den underliggande ordningsprincipen är avhängig dem som ingår i konfigurationen.

Ett antal designelever, vilka ju delar den kollektiva identiteten (framtida) designers, som kommer samman för att diskutera hur en modeshow skall organiseras utgör ett exempel på denna konfiguration. Aktörerna har samma roller och det finns ingen etablerad standard för hur en show skall göras. De måste förhandla fram vad som skall göras, med andra ord vad som värderas, och detta sker utifrån att de har lika roller. Genom interaktion, argumentation, allianser, skvaller, positionering och så vidare uppkommer en idé om hur modeshowen skall göras. Denna process går inte att skilja från att aktörerna differentierar sig. I relation till deras inflytande och bidrag till idén om showen ordnas hierarkiskt en statusordning bland aktörerna. Det framkomna resultatet, vad man skall göra, har ingen hållfasthet vare sig i rum eller i tid bortom dem som varit med och förhandlat fram vad som skall göras. Av detta följer att inträde och utträde i konfigurationen vanligen rekonstruerar statusordningen och värdet i konfigurationen (jfr. Bourdieus diskussion om fält, t.ex. 1996). Det är vidare möjligt att föreställa sig hur möten med standard någon gång startat som ett möte och först ordnats utifrån status. Utifrån detta har man förhandlat eller stridit fram standarden som därefter utgör grunden för värdering inom konfigurationen. Således kan man se hur värden uppstår i denna interaktion. ${ }^{13}$

Det skall tydligt sägas att denna konfiguration ofta uppkommer i fall där aktörer har identiteter "med sig in" i en situation. Dessutom innebär verklighetens identitetsformation att konfigurationer överlagrar varandra. Mötet, och konfigurationen, blir därför betingat av dessa identiteter samt de konfigurationer som de är resultat av. Det är vidare möjligt att tänka sig en modeshow organiserad av organisationer varpå samma analys i grunden kan tillämpas.

Men vad är skillnaden mellan företagsstorlek och modeshow? Skillnaden är att ordning bland verkställande direktörer konstrueras utifrån en standard som de och andra accepterar. Det är en hållfast social konstruktion som så att säga föregår deras interaktion, men som också förstärks genom deltagarnas aktiviteter. Det innebär att deras identiteter är en funktion av nivån på värdeskalan (standarden) de uppnår. I fallet med skapandet av modeshowen konstrueras värdet (vad som utgör ett bra framträdande på modeshowen) parallellt med skapandet av identiteter, och statusordningen är knuten till aktörerna; det är i många fall sociala konstruktioner med relativ låg hållfasthet. I båda fall erhåller dock aktörerna identiteter som ett resultat av deltagande i konfigurationer. 


\section{Gränssnitt}

Gränssnitt skiljer sig från möte genom att aktörerna har olika roller beroende på vilken sida om snittet man befinner sig. Man kan säga att aktörerna möter varandra, men de har olika roller. ${ }^{14}$ En ytterligare uppdelning kan göras mellan gränssnitt där en aktör enbart agerar utifrån rollen som finns på ena sidan gränssnittet (t.ex. producent av kläder) och de där aktören byter sida (och fungerar exempelvis som mäklare eller agenter, dvs. som både köpare och säljare i samma marknad). Gränssnitt kan på samma sätt som möten ha status eller standard som ordningsprincip. Genom dessa distinktioner skapas fyra olika konfigurationer som faller under gränssnitt, vilket alltså syns i Figur 1 ovan. Nedan ges exempel på var och ett av dessa.

Gränssnitt, roll på en sida, Standard. Detta är en vanligt förekommande konfiguration och leverantörer av bomull till tygtillverkare är ett exempel (tillverkningsföretag för kläder är ett annat). Även om identiteter skapas både utifrån rollen som producent och som konsument fokuserar jag här på konfigurationen i vilken de är producenter. Leverantörerna har en stabil roll, dvs. de producerar bomull och har en kollektiv identitet som bomullsproducenter. Det finns dessutom en tydlig kvalitetsstandard för bomull, som upprätthålls i marknaden för bomull (vilket är typiskt för många råvarumarknader). Denna standard uppvisar hög hållfasthet och aktörer i branschen orienterar sig mot den.

Identiteter formas i denna konfiguration som en konsekvens av hur väl aktörer (indirekt via deras produkter) motsvarar det värde som är standardiserat, vilken alltså är den ordningsprincip som används för evaluering. Med andra ord har de olika kvalitet på sin bomull, vilket resulterar i att de får identiteter relativt andra producenter (vilken är den kollektiva identiteten som aktörerna delar). Den standard de orienterar sig emot är oberoende av aktörerna; den påverkas inte av deras handlingar, eller av deras inträden eller utträden i konfigurationen (marknaden). Detta innebär inte att standarden är fixerad; precis som allt annat som är socialt konstruerat så kan den rekonstrueras. Den stora skillnaden är att produktionsstandarden som ordningsprincip har högre hållfasthet än de ordningar som aktörerna på vardera sidan (köpare och producenter) upprätthåller.

Gränssnitt, roll på en sida, Status. Denna konfiguration är omvänd den där standard ordnar identiteter. I fallet med status uppvisar aktörers identiteter på båda sidorna högre hållfasthet än ordningsprincipen (värdet) de konstruerar. Ett konkret exempel på detta är hur mode bestäms som ett resultat av interaktion mellan designers och användare av modekläder. Tydligast märks det med haute couture, dvs. kläder som är unika. Dessa kläder är kostsamma och ett pris på 60000 är snarare regel än undantag. Haute couture modet är en funktion av att aktörer från två statusordningar, designers (inklusive företag med varumärken) och "kändisar", kommer samman i ett gränssnitt. Tillsammans genererar banden mellan designers och kändisar, som går via klädesplagg, mode. Dessa aktörer konstituerar delvis varandra, dvs. en designers status (plats i statushierarkin bland designers) är en funktion av vilka som bär dennes kläder (positionerna av bärarna i denna statushierarki). Det som dessa bär har stor inverkan på mode, dvs. vad som värderas i denna konfiguration. Även om de delvis konstituerar varandra, och är varandras förutsättningar för mobilitet och omdefinition av identitet, har dessa socialt konstruerade statushierarkier högre hållfasthet än modet för de produkter det gäller: haute couture. 
Vissa designers gör traditionella kläder, medan andra gör mer trendsättande och trendkänsliga kläder. Varje designer har sin egen stil. Stilar utgör en horisontell differentiering, men detta utgör inte en ordning, och förtar inte den osäkerhet som råder. Genom interaktion över ett gränssnitt (en marknad) skapas relationer till en annan statusordning (köpare, "kändisar") och designers erhåller status från köparna. I och med detta skapas en horisontell statusordning bland designers. Situationen är densamma för kändisar. Det går alltså inte att separera värde från standarden eller identiteten. De hänger samman och konstitueras parallellt.

Gränssnitt, roll på båda sidorna, Standard. Gränssnitt karaktäriseras alltså av två sidor, var och en med en viss roll som orienterar sig mot den andra sidan. Inom klädbranschen finns det agenter vilka ofta är företag snarare än enskilda individer. De fungerar som mellanhänder mellan tillverkare och inköpare (t.ex., mindre klädkedjor eller grossister). Agenter arbetar framförallt mot mindre inköpare som inte själva har resurser att ha heltidsanställda på plats i ett land. En agent kan företräda både tillverkningsföretag och inköpsföretag. De opererar på en marknad, ett gränssnitt, men deras roll är inte knuten till enbart en sida. De växlar mellan de två sidorna vilket innebär att de ibland uppträder som köpare, ibland som säljare. Det är dock tydligt vad som värderas av dem som deltar i detta gränssnitt, pengar. Aktörerna har en kollektiv identitet som agenter men deras enskilda identiteter är en funktion baserat på standarden - hur väl de genererar pengar.

Gränssnitt, roll på båda sidorna, Status. Den sista konfigurationen innebär att aktörerna skiftar mellan roller i gränssnittet, men det saknas en standard för utvärdering av interaktionen över gränssnittet. Det är tillsammans med Mötet där alla har lika roller, och där status utgör ordningsprincipen, den minst genomskinliga sociala konfigurationen. Genom att det är svårt att tolka vad som händer och hur man skall agera skapar denna typ av gränssnitt stor osäkerhet och stress för aktörerna. Det beror, något tillspetsat, på att aktören varken vet vem hon är eller vad som gör någon till något. Med andra ord är aktören varken säker i en roll, identitet eller vilket värde som etablerats i gränssnittet. Så även om varje aktör är medskapare av ordningsprincipen har hon samtidigt att hantera både osäkerheten om vad som värderas samt rollbyten.

I många professionella grupperingar förekommer sammankomster där aktörer saknar en tydlig identitet, där få tydliga roller förekommer eller inget uppenbart värde centrar sammankomsten. En semiprivat mingelfest där aktörer med olika yrkesroller, kön, åldrar och intressen deltar är ett sådant exempel. Vad man skall prata om och vem som pratar (rollen som "talare" och "lyssnare") är oklar. Talare och lyssnare är två tillfälliga roller som inte innebär permanenta åtaganden, samtidigt som de konstituerar sidorna i gränssnittet. Dessa roller "går runt" bland dem som träffas, då var och en får tala (om än inte i ordning). Under samtalets gång gnuggas det fram vad man talar om och vad som etableras som ett samtalsämne, dvs. ordningsprincipen är inte något en enskild aktör kan bestämma. Genom turtagningar i samtalet konstrueras en ordning om vad man talar om, och hur rollerna skall spelas. Denna ordning liksom hur rollerna skall spelas kan omförhandlas många gånger under en kväll. ${ }^{15}$ Det sker inte minst när nya aktörer träder in och ur kretsen som samtalar, genom turtagning i dialoger, byte av ämnen etcetera, vilket gör att konfigurationen "skakas om" och rekonstrueras.

Det är inte svårt att se hur denna konfiguration kan ha börjat som ett möte, men att den ordnas över tid. Man måste inse att de roller som etablerats här, vilket gör det till 
ett gränssnitt och inte ett möte, i sig kan omförhandlas. Denna typ av konfiguration kan existera under ett fătal sekunder, men om samma personer kommer samma vid flera tillfällen kan konfigurationen bestå under 10-tals år. I det senare fallet kan man även tänka sig att värdet som etablerats kristalliseras till en standard. Som en konsekvens kan aktörer börja bytas ut utan att konfiguration ändar karaktär, vilket innebär aktörer orienterar sig mot värdet som konfiguration innehåller. Konfiguration har därmed institutionaliserats, och den centrerar sig kring ett värde. Men konfigurationen startade inte som en standardordning utan som en statusordning.

Diskussionen ovan visar sammantaget hur ordning i det sociala livet kan studeras utifrån tanken om sociala konfigurationer. De konfigurationer, vilka består av roller, värden, identiteter, som genereras kan i vissa fall ha mycket hög hållfasthet. I andra fall är den lägre och mer lättföränderlig. Det visar att roll, identitet, ordning och värde samskapas; de kan inte studeras var för sig. Konfigurationer bidrar till att skapa ordning i kaos, genom att värden och social struktur institutionaliseras. Det innebär dock inte att de är oförändliga. Vidare, som visats, är konfigurationer i högst varierande grad institutionaliserade. Detta gör att en samhällsvetenskaplig analys inte kan nöja sig med en institutionell analys, då den är statisk och inte kan är lämpad för preinstitutionella situationer och förlopp.

\section{Unika identiteter och betydelsen av konfigurationer}

Avsnittet ovan beskriver artikelns huvudpoäng, dvs. hur värden, roller, ordning och enskilda identiteter konstrueras i vad jag kallar sociala konfigurationer som i sig utgör en grund för kollektiv identitet. Jag skall nu gå vidare och väldigt kort ta upp betydelsen de regisserande aktörerna och deras "publik" ger olika konfigurationer. För att kunna diskutera detta bör identitetsformation över tid klargöras, eller med andra ord, formationer av vad som här kallas unika (jfr. personliga) identiteter. Dessa skapas genom att en mängd olika enskilda identiteter hänger samman, eller binds samman kring aktörens "identity peg”" (vilket exempelvis kan vara en kropp när det gäller personer eller ett varumärke när det gäller företag). En unik identitet är i korthet resultatet av de olika identiteter som skapas i de konfigurationer en aktör deltar i, och där narrativs, vilka förmår binda samman enskilda identiteter i olika konfigurationer till en unik identitet, spelar en stor roll. Margaret Somers menar att,

To have some sense of social being in the world requires that lives be more than different series of isolated events or combined variables and attributes. Ontological narratives process events into episodes ... Thus narrative embeds identities in time and spatial relationships. (Somers 1994: 618)

En aktör är varken helt disintegrerad, dvs. den har inte helt olika identiteter i de konfigurationer som aktören deltar i, eller en helt integrerad identitet som inte uppvisar några skillnader mellan de olika konfigurationerna. Detta beror delvis på att aktörer regisserar identitet i olika konfigurationer (jfr. Aspers 2002), men också på att de aktörer som finns i omgivningen har olika uppfattningar om konfigurationer. En aktör må framställa sig som en toppdesigner på grund av att hon deltar i en lokal tävling. Men om dem hon interagerar med inte anser att hennes deltagande i denna konfiguration 
gör henne till kläddesigner, och om de inte heller betraktar henne, eller orientera sina handlingar mot henne som en designer, så är hon heller i en sociologisk betydelse en designer. ${ }^{16}$ Ett annat exempel på hur en identitet endast delvis kan regisseras är då en person som är hyllad designer försöker avsäga sig sin roll, vilket i det närmaste är omöjligt. Karl Lagerfeld, Vivienne Westwood och Yves Saint Laurent är för evigt identifierade av andra aktörer, och i vid mening "publiken", med design. I social interaktion, menar Goffman (1971: 1-27), försöker aktörer att kontrollera sitt framträdande och genom detta påverka hur den sociala situationen definieras. Verklighetens fall hamnar ofta mellan de som förgäves försöker regissera sin unika identitet till något ingen skulle hålla med om och de som inte kan undkomma sin identitet. Det är uppenbart att en empirisk analys inte kan falla tillbaka på någon av dem. ${ }^{17} \mathrm{Med}$ andra ord har de flesta aktörer någon möjlighet att regissera identiteten i en konfiguration, samtidigt som de inte kan undkomma andras konstruktion av den (jfr. Zuckerman et al. 2003). Det har att göra med det faktum att konfigurationer är knutna till värden, som, så att säga, underbestämmer en identitets vara; ibland helt oavsett aktörens, dvs. en persons eller ett företags, framställande.

Den objektiva värdehierarkin (jfr. Goffmans diskussion om identitetsnormer i 1968: 153-5) strukturerar aktörers möjlighet att regissera identiteter. Goffman (1968: 71) talar vidare om hur "the fingertips of society" sträcker sig ned och påverkar interaktioner och identiteter. Det är tydligt inte minst innan en aktör själv kan reflektera över sin identitet, som exempelvis är fallet för små barn vilka även helt saknar möjligheten att regissera sin identitet.

Det finns normalt en konsensusnivå i ett samhälle om vikten av olika konfigurationer; dvs. en slags värdehierarki som innebär att vissa värden anses viktigare än andra. Kulturbegreppet rymmer denna tanke om att tilldela ordning mellan olika värden (jfr. Parsons 1991). Studien pekar mot det som Parsons hävdade, nämligen att värden är centrala vid analys av den sociala strukturen (Lidz 1991: 31). Med andra ord påverkas aktörers unika identiteter mer av vissa än av andra konfigurationer, oavsett vad de själv tycker.

Men hur fogas de olika utfallen i konfigurationerna, med olika värden och vikt i samhället, samman till en unik identitet? Konfigurationerna som en individ genomgår binds samman via olika grad av regi, dvs. vad en aktör "gives off" (för att tala med Goffman) och skapar en historia vilken konstruerar en unik (personlig) identitet (jfr. Goffman 1968: 74-5; Somers 1994; White 1992; jfr. Aspers 2002). Identiteter är socialt bestämda, men oavsett om en aktören är en person eller en organisation kan regi påverka den unika identiteten.

Hur kan man förstå detta mer konkret? Ett företag deltar exempelvis i en finansiell marknad, i konsumentmarknaden där de säljer sina kläder till konsumenter och även i olika reklam och sponsorsammanhang. De utgör olika enskilda konfigurationer, och var och en av dessa påverkar ett företags unika identitet. Ett företag kan förvisso försöka regissera identiteten, men det går inte att styra hur den totala bilden av de olika identiteterna som skapas i olika konfigurationer uppfattas av exempelvis kunder och konkurrenter. Det innebär exempelvis att ett företag som försöker framställa sig som en högstatusproducent omöjligen kan göra det om de enda som köper produkterna är 12-åriga pojkar.

En poäng som detta avsnitt tillför diskussionen ovan är en mer ingående problematisering av identiteters tidslighet. Varje konfiguration en aktör deltar i är en potentiell källa till att den unika identiteten omformas. Ju mer viktig en konfiguration anses, 
ceteris paribus, ju större möjlighet är det att den unika identiteten påverkas. Vidare, varje konfiguration överlagrar genom historier tidigare identiteter. Genom detta binds aktörens identitet samman. Aktören har dock varierande kontroll över hur deras identitet uppfattas av andra, och det beror delvis på att aktörens historia är känd av andra (jfr. Aspers 2002; Goffman 1968: 79-92). En identitet, för att återknyta till Husserl, innebär alltså att en likhet som föreligger mellan två "saker", t.ex. två handlingar som knyts ihop av ett medvetande, tidigare historia och en kropp. Ett klädföretags unika identitet kan exempelvis ändras radikalt om det framkommer att det har utnyttjat barnarbetare. Även om de flesta uppfattar en viss identitet olika (eftersom få känner till alla de konfigurationer en aktör har deltagit i) finns det tillräckligt mycket som överlappar, och det är ju vad som gör att man överhuvudtaget talar om en unik identitet.

\section{Avslutande diskussion}

Utifrån vad som sagts ovan är det klart att osäkerhet är ett centralt inslag i teorin om sociala konfigurationer och all forskning om social ordning. Osäkerheten om utfallet av en aktörs deltagande i en konfiguration är generellt större vid Status än vid Standard. Om det finns en standard är det lättare att predicera och värdera den insats som en aktör gör. Vid Status är utfallet beroende av andras direkta uppfattningar, till skillnad från Standard där aktörers värderingar över tid kristalliseras i en standard.

Strider om hur standards skall se ut är vanliga. En sida i en marknad kan exempelvis försöka införa betalningsrutiner som gynnar den. Att införa standards är exempelvis ett sätt att gå från Status till Standard och därigenom minska osäkerheten för aktörerna. Genom standards kan man lättare tala om formellt eller informellt institutionaliserade konfigurationer.

Vad kan man säga mer generellt om möjligheten för en aktör att påverka sin unika identitet? Om en aktör hela tiden verkar i samma nätverk är det svårare att förändra den än om aktören deltar i konfigurationer kopplade till olika nätverk. Om person exempelvis lever i ett "alla-känner-alla" samhälle är det svårare att förändra identiteten. Varje ny konfiguration startar så att säga med att alla har sina tidigare identiteter. Identitetsomformateringar kan därför förväntas i samband med separation från etablerade nätverk, exempelvis via byte av arbete, flytt till en annan stad eller till ett annat land. Det märks bland annat när företag försöker etablera sig i en annan, och kanske mer vinstskapande nisch då de går in på en ny marknad (t.ex. ett annat land). I dessa situationer kan aktörer agera strategiskt och "växla spår".

Konfigurationers koppling till uppkomsten av värden är tydlig. Varje ordning som skapas innebär att den uppkommer kopplat till ett värde. Det kan exempelvis vara storlek, skönhet (konkretiserad på olika sätt om det gäller mattor, porslin, hundar eller tånaglar), eller pengar som är värdet. Som indikerats kan vi förstå skapandet av värden som oavsiktliga konsekvenser av skapande och positionerande av identiteter. Inte minst i konfigurationer där möten sker och där ordning kommer sig av att de ingående identiteterna erhåller positioner som är stabila relativt varandra kan man tänka sig att värden som uppstår bidrar till att statusordningar kristalliserar. Genom att vissa aktörer bär med sig makt, utifrån positioner i andra konfigurationer, har de större inflytande vid rekonstruktion av gamla och konstruktion av nya konfigurationer. Men genom detta sociala spel skapas också nya maktbaser. 
Vidare, även om vissa aktörer kan ha mer makt än andra är ingen allsmäktig och ingen konfiguration är för evigt given. Men i konfigurationer som baseras på hållfasta konstruktioner (värden) är sannolikheten mindre för att rekonstruktioner av värden eller ordningen i sin helhet sker. Med andra ord, de konfigurationer som är baserade på hållfasta (värden), som tid, längd och vikt (jfr. Aspers 2001), eller där den sociala ordningen är hållfast, kan benämnas som hållfasta sociala konstruktioner. Det är förstås en empirisk fråga att studera vilka konfigurationer som är mest centrala i samtiden.

Det finns ytterligare områden som denna begreppsapparat kan tillämpas på. Vilka karriärer kräver mycket regiarbete och vilka kräver lite? Har det att göra med hållfastheten hos de ingående sociala konstruktionerna eller finns det andra förklaringar? Vad blir konsekvensen av att betrakta exempelvis personalmöten och personalfester som konfigurationer? Vilka nya perspektiv öppnas upp?

Sammanfattningsvis, det ramverk som presenterats i denna artikel utgår från samhällets komplexitet och hur identiteter formas i konfigurationer samtidigt som de är medskapare av ordning. Det är ett försök att bidra till en diskussion om den sociala ordningens uppkomst och form.

\section{Acknowledgements}

Artikeln har tillkommit genom stöd av Axel och Margaret Ax: son Johnssons stiftelse för allmännyttiga ändamål. Jag vill framförallt tacka de två anonyma bedömarna, redaktionen för Distinktion, samt Magnus Bygren för värdefulla synpunkter som förbättrat denna artikel. Jag vill också tacka Göran Ahrne, Per Bendtz, Marcus Carson, Caroline Dahlberg, Magnus Haglunds, Karin Helmersson-Bergmark, Barbara Hobson, Jens Rydgren, Mikaela Sundberg, Árni Sverrisson, Richard Swedberg och Ryzard Szulkin.

\section{Notes}

1 Med social ordning menar jag hur aktörer, positioner, aktiviteter och regler är möjliga att förutse, vilket innebär att de är relativt stabila (jfr. Eisenstadt 1968).

2 Se Aspers (2005b) för en mer detaljerad diskussion av det empiriska materialet och analysen av det.

3 Därtill finns en omfattande forskning exempelvis om "social identity theory", som främst studerar aktörens relation till gruppen utifrån ett psykologiskt och eller socialpsykologiskt perspektiv (Capozza/Brown 2000). Denna forskning är kopplad till smågruppsforskningen.

4 Identitet är ett fundamentalt begrepp. Husserl insåg dock detta och förtjänar att citeras: "Vi kan inte beteckna två ting som likadana, utan att ange i vilket avseende de är lika; och i detta avseende ligger identiteten. Varje likhet är relaterad till en species, under vilken det som jämförs faller; och denna species är inte något som i sin tur äger endast likhet, och kan inte vara det, då annars den mest förvända regressus in infinitum vore undviklig. När vi anger det avseende som jämförelsen gäller, hänvisar vi genom en mer allmän släktterm till den krets av specifika differenser, inom vilken den differens som uppträder identiskt hos de jämförda elementen befinner sig. Om två ting är lika med avseende på form, så är ifrågavarande formspecies det identiska; är de lika med avseende på sin färg, så är det identiska en färgspecies osv. Alla species har emellertid inte fått ett entydigt avtryck i språket, och så kan det ibland saknas ett passande uttryck för det avseende jämförelsen gäller, det kan vara svårt att ange det klart; men vi har likväl blicken på detta avseende, och det bestämmer vårt tal 
om likhet ... Identitet är något absolut odefinierbart, till skillnad från likhet. Likheten är förhållandet mellan föremål som faller under en och samma species" (Husserl 2000: 142 3). Man kan säga med den tidige Husserl, som försöker utveckla en ideal logik, att det med nödvändighet måste finnas något som utgör identiteten.

5 Goffmans begrepp social identitet tangerar vad jag här kallar kollektiv identitet. Skillnaden är att social identitet handlar om roller. Se även diskussionen om Goffmans begrepp virtuell social identitet (Burns 1992: 212 3) och jämför med Berger och Luckmann (1991: 194 200).

6 Se Aspers (2005a: 19 23) och Azarian (2003) för utförligare diskussioner om Whites teori.

7 I samtal med White (Köln 2005-05-18) har han själv indikerat problem med detta kapitel. 8 Whites ansats har onekligen en "fenomenologisk" ambition (t.ex. 1992: 63), men hans teori startar inte från en fenomenologisk grund.

9 Även om exempelvis Norbert Elias också använt begreppet konfiguration samt talat om en konfigurationssociologi (t.ex. Elias/Dunning 1966: 397) finns det en stor skillnad jämfört med hur begreppet används i denna artikel. Elias begrepp har en stark rumslig dimension, precis på samma sätt som begreppet har inom området arkitektur. Hans begrepp betonar även regler och social struktur (Elias/Dunning 1966). I min användning är värde, ordning och identitet centrala komponenter. Inte minst tanken om ordningsprincip och jämförelse mellan aktörer är mycket viktig, något som saknas hos Elias.

10 Roll handlar om vad man gör i samhället, identitet om vem man är (Frank/Meyer 2002: 86, n. 1; jfr. Aspers 2002). Olika roller skiljer sig normalt åt även på andra sätt än vad man gör, t.ex. skiljer sig ofta regler och "intressen" mellan roller. Det är av vikt att skilja på roll, som exempelvis Parsons använder begreppet, och identitet som det används här. Hos Parsons fyller roller funktioner, men en identitet, vare sig den är enskild, kollektiv eller unik, fyller i sig inte någon funktion. En central poäng med identitet är att aktörer inte kan skiljas från sina identiteter, vilket är möjligt från en roll. Detta visas mer tydligt i exemplen nedan där aktörer kan byta mellan olika roller, men likväl bevara sina identiteter.

11 Jämförelse förutsätter någon slags värdeskala, och värdet i konfigurationen utgör en "normativ" dimension. Parsons (1991: 38) diskuterar detta, och han talar om att värden (values) måste förstås i relation till evaluering ("evaluation"). Husserl har analyserat ett snarlikt förhållande, normativa satser, och säger att "varje normativ sats forutsätter ett visst slags värdehållning (gillande, uppskattning), genom vilket begreppet om något $\mathrm{i}$ bestämd mening 'bra' (värdefullt) resp. 'dåligt' (värdelöst) uppkommer med avseende på en viss klass av objekt; i enlighet med denna hållning delar sig sedan dessa objekt i bra och dåliga ... De positiva och relativa värdepredikatens konstitutiva innehåll är så att säga de måttenheter med vilka vi mäter objekt på området i fråga" (1998: 57 9). Området kan i detta avseende likställas med det en konfiguration täcker och objekt motsvarar vad som värderas, t.ex. skönhet (hos ett visst objekt) eller kvaliteten (för exempelvis en mascara).

12 Denna standard bygger på sociala konstruktioner. Man kan tala om lager av konstruktioner som bygger upp varandra. En konstruktion är mer hållfast om den bygger på andra konstruktioner som är mer eller mindre förgivettagna än om de är starkt debatterade (jfr. Aspers 2001). Med andra ord är vissa meningar mer stabila konstruktioner än andra och mer förgivettagna.

13 Detta är ett förslag i debatten om hur värden uppstår (jfr. Joas 1997). Joas förslag utgår från individen och att värden uppstår genom självtranscendens. Vad som diskuteras här är ett mer sociologiskt angreppssätt. Nietzsche diskuteras även av Joas och just Nietzsches tänkande är startpunkten för en diskussion om hur värden uppstår i interaktion (Aspers forthcoming), se även White (1992).

14 Det finns åtminstone en ytterligare dimension som kan dras in, men som i sak inte påverkar vad som sägs här, nämligen det faktum att många gränssnitt är sammankopplade i kedjor. I en klädproduktionskedja har företag dels identiteten som inköpare av varor, men deras huvudsakliga identitet uppstår som producenter när de så att säga vänder sig om och möter 
slutkonsumenter på klädkonsumtionsmarkanden (jfr. White 2002).

15 Det finns naturligtvis en hel del olika koder för hur man skall bete sig (jfr. Eliasoph/Lichterman 2003), vilka ger struktur åt samtalet.

16 Man kan förstå patologiska tillstånd på detta sätt, dvs., om skillnaden mellan upplevd, eller subjektiv, identitet och uppfattad,

\section{Referenser}

Aspers, Patrik (1997): 'Vetenskaplig Realism', Sociologisk Forskning 4: 7380.

Aspers, Patrik (2001): 'Vad skulle det annars vara Om socialkonstruktivism', Sosiologi idag 39(2): 2339.

Aspers, Patrik (2002): 'Interaktionsformer', Sociologisk Forskning 1: 627.

Aspers, Patrik (2005a): Markets in Fashion. A Phenomenological Approach. London: Routledge.

Aspers, Patrik (2005b): 'Ethics in Global Garment Chains', kommande in Nico Stehr (ed) The Moralization of Markets. New Brunswick, N.J.: Transaction Press.

Aspers, Patrik (forthcoming): 'Friedrich Nietzsche as a Sociologist', in Jürgen Backhaus/ Wolfgang Drechsler (eds) Friedrich Nietzsche and his Legacy for the Social Science. Dordrecht: Kluwer Academic Publisher.

Azarian, Reza (2003): The General Sociology of Harrison White. Stockholm: Department of Sociology.

Berger, Peter/Thomas Luckmann (1991 [1966]): The Social Construction of Reality. A Treatise in the Sociology of Knowledge. London: Penguin Books.

Bourdieu, Pierre (1996 [1992]): The Rules of Art. Genesis and Structure of the Literary Field. Stanford: Stanford University Press.

Brubaker, Rogers/Frederick Cooper (2000): 'Beyond "Identity", Theory and Society 29: 147.

Burns, Tom (1992): Erving Goffman. London: Routledge.

Burt, Ronald (1992): Structural Holes. The Social Structure of Competition. Cambridge, Mass.: Harvard University Press.

Capozza, Dora/Rupert Brown (eds) (2000): Social Identity Processes. London: Sage. eller objektiv, identitet är stor (jfr. Goffman 1968).

17 Det som avses med en unik identitet är alltså inte postmodern identitetsteori, karikerad av Don Slater, där, "society appears as a kind of fancy-dress party in which identities are designed, tried on, worn for the evening and then traded in for the next" (1997: 30).

Cerulo, Karen (1997): 'Identity Construction, New Issues, New Directions', Annual Review of Sociology 23: 385409.

Eisenstadt, Shmuel (1968): 'The Development of Sociological Thought', pp. 2336 in David Sills (ed) International Encyclopaedia of the Social Sciences, Vol. 15. London: The Macmillan Company.

Elias, Norbert/Eric Dunning (1966): 'Dynamics of Group Sports with Special Reference to Football', The British Journal of Sociology 17(4): 388402.

Eliasoph, Nina/Paul Lichterman (2003): 'Culture in interaction', American Journal of Sociology 108(4): 75394.

Frank, DaviJohn/John Meyer (2002): 'The Profusion of Individual Roles and Identities in Postwar Peroiod', Sociological Theory 20(1): 86105.

Goffman, Erving (1971 [1959]): The Presentation of Self in Everyday Life. London: Penguin Books.

Goffman, Erving (1968 [1963]): Stigma. Notes on the Management of Spoiled Identity. Ringwood: Penguin Books.

Husserl, Edmund (1998 [1913]): Logiska undersökningar, band 1, Prolegomena till den rena logiken. Stockholm: Thales.

Husserl, Edmund (2000 [1913]): Logiska undersökningar, band 2, undersökningar kring kunskapens fenomenologi och teori I-IV. Stockholm: Thales.

Joas, Hans (1997): Die Entstehung der Werte. Frankfurt am Main: Suhrkamp.

Lidz, Victor (1991): 'The American Value System', pp. 2236 in Roland Robertson/Bryan S. Turner (eds) Talcott Parsons: Theorist of Modernity. London: Sage.

Parsons, Talcott (1991): 'A Tentative Outline of American Values', pp. 3765 in Roland Ro- 
bertson/Bryan S. Turner (eds) Talcott Parsons: Theorist of Modernity. London: Sage.

Slater, Don (1997): Consumer Culture and Modernity. Cambridge: Polity Press.

Somers, Margaret (1994): 'The Narrative Constitution of Identity: A Relational and Network Approach', Theory and Society 23: 60549.

White, Harrison (1992): Identity and Control. A Structural Theory of Social Action. Princeton: Princeton University Press.
White, Harrison (2002): Markets from Networks. Socioeconomic Models of Production. Princeton: Princeton University Press.

Zuckerman, Ezra et al. (2003): 'Robust Identities on Nonentities? Typecasting in the Feature-Film Market', American Journal of Sociology 108(5): 101874.

Patrik Aspers är fil.dr, docent och forskarassistent vid sociologiska institutionen, Stockholms universitet, samt Wissenschaftliche Mitarbeiter vid Das Max-Planck-Institut für Gesellschaftsforschung i Köln. Han forskar främst om ekonomisk sociologi och sociologisk teori. Den senaste bokpublikationen är Markets in Fashion. A Phenomenological Approach (Routledge 2005).

\author{
Patrik Aspers \\ Sociologiska institutionen \\ Stockholms universitet \\ 10691 Stockholm \\ Sweden \\ patrik.aspers@sociology.su.se
}

